\title{
Mascarpone cheese from sheep's milk - a new option for the consumer
}

\author{
Félix Roman MUNIEWEG ${ }^{1}$, Emiliane Rodrigues GAVIÃO ${ }^{2}$, Marcela CZARNOBAY $^{3}$, Amanda DILDA ${ }^{4}$, \\ Lenita de Cássia Moura STEFANI ${ }^{5,7^{*}}$, Cássia Regina NESPOLO 6 (1D)
}

\begin{abstract}
Dairy sheep farming, as well as processing of dairy products, are consolidated activities in Brazil, mainly for the production of cheese and yogurt. Considering that sheep milk has high levels of fat and the need for product diversification, this work aimed to develop a new formulation of mascarpone cheese using sheep's milk, since the basis for this type of cheese is milk cream. The quality of this derivative was monitored for 120 days of storage under refrigeration to evaluate microorganisms that indicate quality and safety, in addition to physical-chemical parameters. The ovine mascarpone cheese showed adequate microbiological results, in accordance with the Brazilian legislation, in addition to high total fat, fat content in the dry extract and protein. The physical-chemical and microbiological parameters remained adequate throughout the storage period under maximum temperatures below $7{ }^{\circ} \mathrm{C}$. Mascarpone cheese was classified by its moisture and fat content in the dry extract as medium moisture or semi-hard cheese and as extra fat or double cream cheese, respectively. The processing, packaging and storage conditions proved to be adequate and provided product stability. In this study a new sheep milk derivative was successfully developed, characterized, tested and proved to be adequate for the market.
\end{abstract}

Keywords: food safety and quality; ovine milk; shelf life; dairy products.

Practical Application: The development of mascarpone cheese using sheep milk resulted in an innovative and differentiated product. The tests established the production protocol, verified the commercial conditions of packaging and storage and the quality of the product during the shelf life. The data presented for production of mascarpone can be used by dairy industries to develop similar products.

\section{Introduction}

Mascarpone is a cheese originally from Italy (Capozzi et al., 2020; Carminati et al., 2001), but it is currently produced in other parts of the world, usually from bovine milk (Almeida et al., 2018; Buratto, 2010; Kapetanakou et al., 2017). It is an unripened fresh cheese, used for consumption shortly after its production (Capozzi et al., 2020; Carminati et al., 2001; European Comission, 2017) with a delicate, soft, dense, creamy and smooth appearence and color that varies from snow white to light yellow. Fat content is quite high varying from $44 \%$ to $47 \%$ and it may contain over $80 \%$ of fat in the dry extract (Buratto, 2010; Capozzi et al., 2020; Troiani, 2015). Unlike other cheeses, it is produced from milk cream and for this reason, it is soft with good spreadability and smells like milk cream, butter or yogurt (Capozzi et al., 2020; Troiani, 2015; European Comission, 2017). The sweet flavor is noticed, with a slight acidic taste and without sensory aspects such as salty and spicy flavors. In addition, it has high moisture and a melting sensation when tasted (Troiani, 2015).
The production of mascarpone starts by obtaining a cream using centrifugation or keeping the milk at rest for 24 hours at $10-12{ }^{\circ} \mathrm{C}$ in order to favor a slight fermentation (Troiani, 2015). The cream goes through a direct acidification by citric, lactic, tartaric or acetic acid, with the possibility of adding milk, and heating to force coagulation (Buratto, 2010; Capozzi et al., 2020; Carminati et al., 2001; European Comission, 2017; Troiani, 2015). Subsequently, the draining takes place for about 20 hours, and after that the mass is homogenized and packaged (Troiani, 2015).

Ovine milk contains higher levels of solids than bovine milk and sheep milk produced in Brazil shows fat and protein levels varying from 5.9 to $8.8 \%$ and 4.0 to $6.0 \%$, respectively (Balthazar et al., 2017; Barros et al., 2020; Munieweg et al., 2017; Nespolo and Brandelli, 2012; Tribst et al., 2020). This ensures greater industrial performance in cheese production, especially in the case of mascarpone, since it is produced from cream. One of the incentives for sheep farming is the high price paid for sheep's milk, which reaches five times higher than the price

${ }^{1}$ Universidade Federal do Pampa - UNIPAMPA, Campus Uruguaiana, Uruguaiana, RS, Brasil

${ }^{2}$ Universidade Federal do Pampa - UNIPAMPA, Campus Itaqui, Itaqui, RS, Brasil

${ }^{3}$ Instituto Federal de Educação, Ciência e Tecnologia - IFRS, Bento Gonçalves, RS, Brasil

${ }^{4}$ Curso de Zootecnia, Universidade do Estado de Santa Catarina - UDESC, Chapecó, SC, Brasil

${ }^{5}$ Departamento de Ciência e Tecnologia, Universidade do Estado de Santa Catarina - UDESC, Florianópolis, SC, Brasil

${ }^{6}$ Universidade Federal do Pampa - UNIPAMPA, Campus São Gabriel, São Gabriel, RS, Brasil

${ }^{7}$ Universidade do Estado de Santa Catarina - UDESC, Centro de Educação a Distância - CEAD, Florianópolis, SC, Brasil

*Corresponding author: lenita.stefani@udesc.br 
paid for a liter of bovine milk (Nespolo \& Brandelli, 2012; Zucatti et al., 2015). Sheep milk is little consumed in its fresh form and its derivatives have a high commercialization value in Brazil, in addition to differentiated sensory characteristics (Balthazar et al., 2017; Balthazar et al., 2017; Barros et al., 2020; Munieweg et al., 2017; Onofre et al., 2020; Tribst et al., 2020), which is also appreciated in mascarpone cheese (Capozzi et al., 2020; Troiani, 2015). The development of a novel product, such as sheep's milk mascarpone is in line with the new trends of the Brazilian market, which has an interest in dairy products from other types of milk with enhanced functional properties, texture and flavors (Balthazar et al., 2017; Balthazar et al., 2019; Barros et al., 2020; Onofre et al., 2020).

The development of mascarpone cheese with sheep's milk represents a differentiated product not yet found in the Brazilian market. In addition, its production represents a way to use fat obtained from the partial skimming done before the production of most derivatives. Taking all of these into consideration, the objective of this work was to develop and test a novel formulation for mascarpone cheese using sheep's milk as a way to diversify the production of this dairy industry and to evaluate its microbiological and physical-chemical quality during its shelf-life.

\section{Materials and methods}

Mascarpone cheese was produced with Lacaune sheep's milk and cream from a commercial cheese plant located in Bento Gonçalves city $\left(29^{\circ} 10^{\prime} 26^{\prime \prime} \mathrm{S}\right.$ and $\left.51^{\circ} 31^{\prime} 7^{\prime \prime} \mathrm{W}\right)$, Southern Brazil. A flowchart for mascarpone cheese production is shown in Figure 1. Pasteurized milk was added to pasteurized cream in the proportion of $30 \%$ milk and $70 \%$ cream. The mixture was

\begin{tabular}{|c|c|}
\hline \multicolumn{2}{|c|}{ Refrigerated raw sheep milk (below $\left.4^{\circ} \mathrm{C}\right)$} \\
\hline \multicolumn{2}{|c|}{$\downarrow$} \\
\hline Milk pasteurization & Cream pasteurization \\
$\left(72-75^{\circ} \mathrm{C} / 16-20 \mathrm{~s}\right)$ & $\left(85^{\circ} \mathrm{C} / 8 \mathrm{~min}\right)$ \\
\hline
\end{tabular}

\begin{tabular}{|c|}
\hline $\begin{array}{c}\text { Adding milk to the cream } \\
\text { (30\% milk; } 70 \% \text { milk cream) }\end{array}$ \\
$\downarrow$ \\
\hline Heating the mixture up to $95^{\circ} \mathrm{C}$ \\
$\downarrow$ \\
\hline $\begin{array}{c}\text { Addition of citric acid } 10 \% \\
(10 \mathrm{~mL} / \mathrm{kg} \text { of the mixture })\end{array}$ \\
$\downarrow$ \\
\hline Stirring until complete coagulation \\
$\downarrow$ \\
\hline Packaging \\
$\downarrow$ \\
\hline Refrigerated storage $\left(5^{\circ} \mathrm{C} \pm 1.5^{\circ} \mathrm{C}\right)$ \\
\hline
\end{tabular}

Figure 1. Flowchart for the production of sheep's milk mascarpone cheese. homogenized, heated and citric acid $(10 \mathrm{~mL} ; 10 \%)$ was added for each $\mathrm{kg}$ of this mixture, with stirring until complete coagulation.

The mascarpone was packaged into $100 \mathrm{~g}$ plastic jars with heat sealing closure. The samples were transported to the laboratory, in isothermal boxes, containing recyclable ice to keep the temperature below $4{ }^{\circ} \mathrm{C}$, and randomly arranged in a refrigerated chamber at $5{ }^{\circ} \mathrm{C} \pm 1.5^{\circ} \mathrm{C}$. Sampling occurred on day 1 and every 30 days up to 120 days of cold storage, with three bottles being randomly collected in each analysis time.

Microbiological analysis included total and thermotolerant coliforms, total aerobic mesophiles, psychrotrophic, molds and yeasts, in addition to coagulase positive Staphylococcus with samplings every thirty days of storage. Salmonella sp. and Listeria monocytogenes analysis were performed only at the end of the storage period. For coliform quantification, the multiple tube technique with inverted Durhan tubes was used, in series of three tubes. The presumptive test was performed in tubes containing sodium lauryl sulfate broth (Dinamica) and the presence of total coliforms was confirmed in bright green broth with $2 \%$ of lactose bile (Himedia) followed by incubation at $35^{\circ} \mathrm{C}$ for 24-48 hours, while thermotolerant coliforms were in EC broth (Himedia) incubated at $45^{\circ} \mathrm{C}$ for $24-48$ hours. The quantification of the most probable number (MPN) was through the Hoskins table. Total aerobic mesophiles counts were done by plating the sample on Standard Count Agar (PCA) (Oxoid), with incubation at $37^{\circ} \mathrm{C}$ for $24-48$ hours. The psychrotrophic count was in PCA (Oxoid) and incubated at $7^{\circ} \mathrm{C}$ for 10 days. For molds and yeasts, the inoculation was on the surface of the Potato Dextrose Agar (BDA) (Oxoid), with incubation at $25^{\circ} \mathrm{C}$ for 5 to 7 days (Brasil, 2018; Silva et al., 2017). The determination of Staphylococcus sp. was performed on the surface of Baird-Parker Agar (Himedia), enriched with $0.01 \%$ potassium tellurite and egg yolk, and incubated at $36^{\circ} \mathrm{C}$ for 48 hours. After counting the plates with Staphylococcus sp., characteristic colonies for S. aureus (black with halos) were transferred to the Brain Heart Infusion (BHI) medium (Himedia) and incubated at $37^{\circ} \mathrm{C}$ for 24 hours, with subsequent catalase and coagulase tests. The catalase test was performed with a $3 \%$ hydrogen peroxide solution and the conjugated coagulase test used rabbit plasma (Probac) (Silva et al., 2017). Samples for determining the presence of Salmonella sp. were pre-incubated at $37^{\circ} \mathrm{C}$ for 24 hours, in $0.1 \%$ buffered peptide water. Subsequently, the Petrifilm rapid method was used, following the manufacturer's instructions (3M, 2020). To determine the presence of L. monocytogenes, the VIDAS rapid method was used, following the manufacturer's instructions (Biomérieux, 2018).

The physical-chemical evaluation included determination of acidity in lactic acid, total protein, $\mathrm{pH}$, water activity, moisture, fat and fat in the dry extract. Acidity, protein, moisture and fat were determined by official methodologies (Brasil, 2018). Moisture and fat were used to calculate the fat content in the dry extract (Brasil, 2018). Moisture and fat content in the dry extract were used for cheese classification according to the Brazilian legislation (Brasil, 1996). The water activity $\left(a_{\mathrm{w}}\right)$ was evaluated in a device model Aqualab 4TE (Decagon), according to the manufacturer's manual (Meter Group, 2018) and the $\mathrm{pH}$ 
was determined in a pH meter model pg1800 (GGHAKA), with the sample diluted in distilled water (Brasil, 2018).

Microbiological counts were converted into logarithms (log), means and standard deviations from the mean were calculated. The data were evaluated using the SigmaPlot 12.0 program, where analysis of variance was applied followed by the Tukey test at the $5 \%$ level of significance.

\section{Results and discussion}

Total counts for aerobic mesophiles microorganisms, psychrotrophic and molds and yeasts over the storage of sheep's milk mascarpone cheese are shown in Figure 2. Figure 2A shows an average count for total aerobic mesophiles quite variable over time, starting at $4.28 \log \mathrm{CFU} / \mathrm{g}$ on day 1 and ending at $2.10 \mathrm{log}$ $\mathrm{CFU} / \mathrm{g}$ after 120 days. There was a significant decrease $(\mathrm{p}<0.05)$ between 30 and 120 days, which can be explained by the fact that total aerobic mesophiles have an optimum growth temperature between 30 and $40^{\circ} \mathrm{C}$ (Forsythe, 2013) and mascarpone cheese

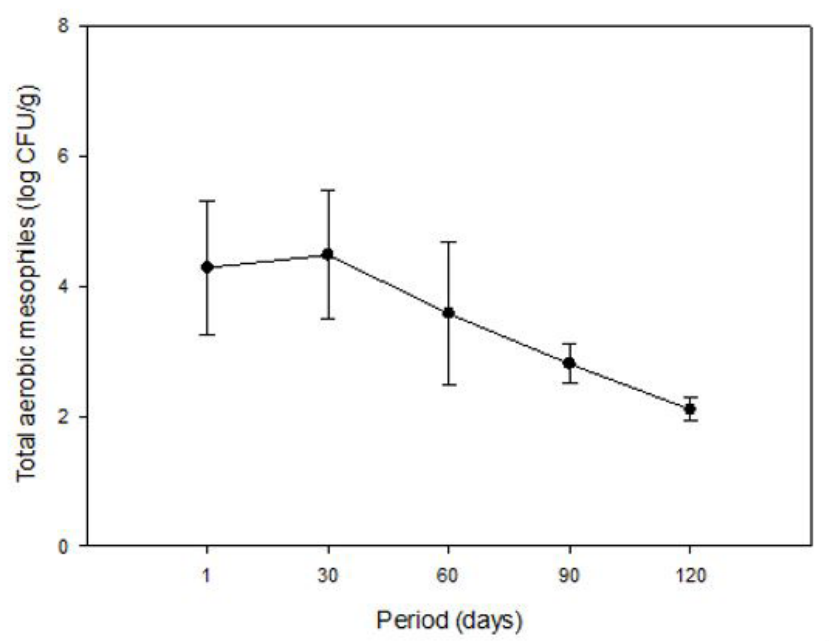

was stored in temperatures below the ideal for the development of these microorganisms. Total aerobic mesophiles can be used to estimate the microbiological quality of dairy derivatives, where values above $5 \log$ UFC/mL may indicate hygienic deficiencies in production (Forsythe, 2013; Funck et al., 2015; Tribst et al., 2020). Therefore, the average results for the mascarpone cheese did not fit in poor hygienic conditions. A study with commercial mascarpone cheese found that the total mesophiles count started at $2 \log \mathrm{CFU} / \mathrm{g}$ and reached $8 \log \mathrm{CFU} / \mathrm{g}$ after 20 days of storage at $7{ }^{\circ} \mathrm{C}$ (Kapetanakou et al., 2017), counts well above those of sheep milk mascarpone.

The evaluation of psychrotrophic microorganisms (Figure 2B) demonstrated that there was no significant difference $(\mathrm{p}<0.05)$ between the counts, with $4.12 \log \mathrm{CFU} / \mathrm{g}$ on day 1 and $2.10 \log \mathrm{CFU} / \mathrm{g}$ at 120 days. The presence of Pseudomonas sp., a psychrotrophic bacterium, was investigated in mascarpone cheese marketed in Greece and the count was $2 \log$ CFU/g (Kapetanakou et al., 2017), a similar value observed at the end of the storage period for

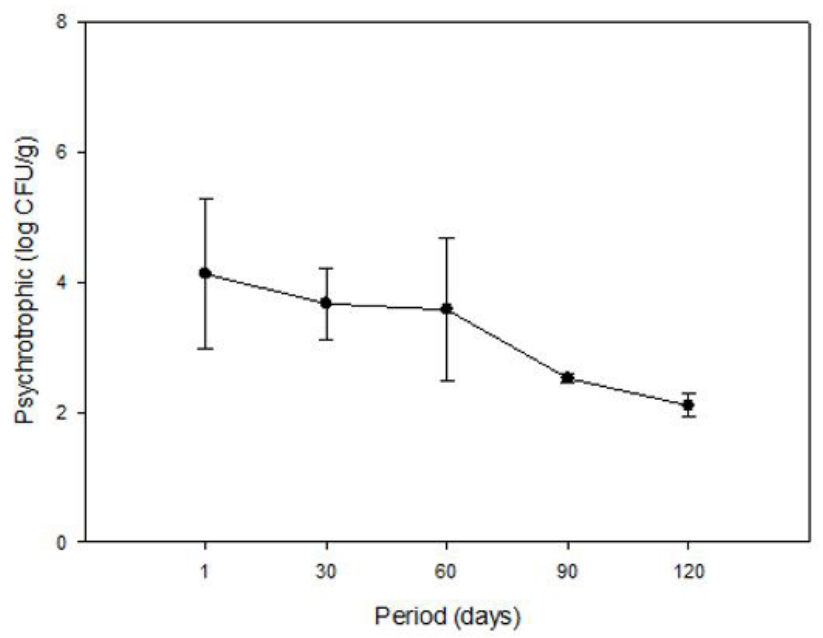

A

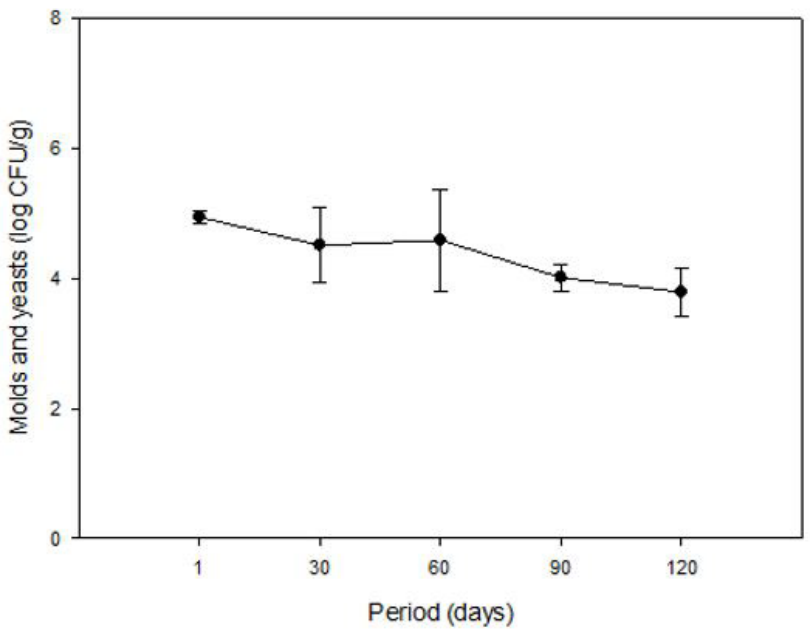

C

Figure 2. Counts of total aerobic mesophiles (A), psychrotrophic (B) and molds and yeasts (C) in mascarpone cheese from sheep's milk. The dots indicate the means and the bars indicate the standard deviation of the mean $(n=3)$. 
sheep mascarpone. A study with Pseudomonas sp. isolated from different foods noted that all of them $(n=66)$ grew at $10{ }^{\circ} \mathrm{C}$. In addition, the cultivation in mascarpone agar, containing $50 \%$ of mascarpone in its composition, resulted in the production of a blue pigment in $15 \%$ of these isolates $(n=10)$, all isolated from milk and dairy products (Caldera et al., 2016). Psychrotrophs have the ability to multiply in refrigeration temperatures and to produce enzymes, such as proteases and lipases, which can compromise the quality of derivatives (Caldera et al., 2016; Forsythe, 2013), so monitoring this group of microorganism is important. The quantification of molds and yeasts (Figure 2C) started with $4.94 \log \mathrm{CFU} / \mathrm{g}$ on day 1 and reached $3.79 \log \mathrm{CFU} / \mathrm{g}$ on day 120 , without significant variations $(\mathrm{p}<0.05)$. In commercial mascarpone cheese stored at $7^{\circ} \mathrm{C}$, the values remained close to $2 \log$ CFU/g over 20 days (Kapetanakou et al., 2017). Although Brazilian legislation does not establish a limit for this group, it is known that yeasts are capable of growing in milk and dairy products due to their ability to assimilate and ferment lactose, produce lipases and extracellular proteases (Facchin et al., 2013).

Table 1 shows the results for total coliforms, thermotolerant coliforms and $S$. aureus. It can be seen at the end of the table that the limits established by the legislation of the Ministry of Agriculture (Brasil, 1996) are different from those determined by the legislation of the Ministry of Health (Brasil, 2001) and the product must follow the legislation of the agency with which it is registered. The counts in mascarpone cheese from sheep's milk did not exceed any of the limits. The average values for total coliforms were in the order of $2 \log \mathrm{MPN} / \mathrm{g}$ on the first day of analysis, decreasing significantly $(\mathrm{p}<0.05)$ from this collection to less than $0.48 \log \mathrm{MPN} / \mathrm{g}$. In commercial mascarpone, the values were in the order of $1 \mathrm{log}$ CFU/g (Kapetanakou et al., 2017). The total coliform group is an indicator of hygienic-sanitary quality of the raw material to obtain the product (Forsythe, 2013), and these results indicated that good practices were observed during the mascarpone processing chain.

The highest count of thermotolerant coliforms occurred on day one, with 2.09 log MPN/g and dropped to $0.48 \log \mathrm{MPN} / \mathrm{g}$ on day 120. In colonial cheeses produced in Southern Brazil, the values were above $2 \log$ MPN/g (Funck et al., 2015), also

Table 1. Total counts for coliforms, coliforms thermotolerants and Staphylococcus aureus in mascarpone cheese made of sheep's milk.

\begin{tabular}{cccc}
\hline Period (Days) & $\begin{array}{c}\text { Total coliforms } \\
(\log \mathrm{MPN} / \mathrm{g})\end{array}$ & $\begin{array}{c}\text { Fecal coliforms } \\
(\log \mathrm{MPN} / \mathrm{g})\end{array}$ & $\begin{array}{c}\text { Staphylococcus } \\
\text { aureus }(\mathrm{log} \\
\text { CFU/g) }\end{array}$ \\
\hline 1 & $2.09 \pm 1.07^{\mathrm{a}}$ & $1.23 \pm 0.63^{\mathrm{a}}$ & $2.59 \pm 0.11^{\mathrm{a}}$ \\
30 & $>0.48^{\mathrm{b}}$ & $>0.48^{\mathrm{b}}$ & $2.26 \pm 0.50^{\mathrm{ac}}$ \\
60 & $>0.48^{\mathrm{b}}$ & $>0.48^{\mathrm{b}}$ & $1.33 \pm 0.58^{\mathrm{bc}}$ \\
90 & $>0.48^{\mathrm{b}}$ & $>0.48^{\mathrm{b}}$ & $1.26 \pm 0.24^{\mathrm{bc}}$ \\
120 & $>0.48^{\mathrm{b}}$ & $>0.48^{\mathrm{b}}$ & $0.99 \pm 0.70^{\mathrm{b}}$ \\
Limit by law $^{*}$ & Below 3.7 & Below 2.7 & Below 3.0 \\
Limit by law $^{* *}$ & Below 3.0 & Below 3.0 & Below 3.0 \\
\hline
\end{tabular}

Mean values \pm standard deviation of the mean $(n=3)$; Different letters in the same column indicate a statistically significant difference $(\mathrm{p}<0.05)$; Values related to medium moisture cheeses, between 36 and $46 \%$, according to Brazilian legislation ( ${ }^{\star B r a s i l, ~ 1996 ; ~}$ ${ }^{* *}$ Brasil, 2001). not exceeding the limits of the legislation. Coliform group is an indicator of hygienic-sanitary quality and high counts in dairy products may indicate hygiene failures during milking, refrigerated milk storage or dairy processing (Forsythe, 2013; Munieweg et al., 2017). The average counts of $S$. aureus ranged from 2.59 to $0.99 \log \mathrm{CFU} / \mathrm{g}$, with significant variations over refrigerated storage, but without exceeding the maximum limits established by Brazilian legislation for cheeses with this moisture content. The evaluation of Salmonella sp. and L. monocytogenes indicated the absence of both in $25 \mathrm{~g}$ of mascarpone cheese from sheep's milk, in accordance with the legal parameters (Brasil, 1996; Brasil, 2001). This monitoring is important since they are pathogenic bacteria and are associated with contamination in dairy products (Forsythe, 2013; Kapetanakou et al., 2017; Lim et al., 2019), especially Listeria sp., which is constantly associated with outbreaks involving creamy, fresh cheese or whey (Kapetanakou et al., 2017; Lim et al., 2019).

Titratable acidity, protein, moisture, fat and fat in dry extract in mascarpone cheese from sheep milk during cold storage are shown in Figure 3. The initial average acidity was $0.25 \%$ of lactic acid and $0.26 \%$ of acid lactic acid at 120 days (Figure $3 \mathrm{~A}$ ), without significant variations $(\mathrm{p}<0.05)$. In a formulation of bovine Mascarpone, the acidity increased from $0.32 \%$ lactic acid on day 1 to $0.37 \%$ of lactic acid after 30 days (Almeida et al., 2018), higher than those observed with sheep's milk. Since mascarpone is a cheese obtained from an acid-added coagulation, a higher titratable acidity value is expected according to the amount of acidic solution added. The average protein content (Figure 3B) showed a minimum of $3.87 \%$ and a maximum of $4.70 \%$, with no significant differences between sampling $(\mathrm{p}<0.05)$. The protein contents observed in commercial brands of mascarpone were $4.06 \%$ (Almeida et al., 2018), between 4.64 and 6.90\% (Buratto, 2010), $5.70 \%$ (Carvalho et al., 2015) and from 3.33 to $7.14 \%$ (United States Department of Agriculture, 2019). The protein content in mascarpone depends on the composition of raw materials of sheep origin, which in sheep's milk obtained in Brazil varied from 5.5 to $6.0 \%$ of protein (Munieweg et al., 2017), and in the cream used in production of Mascapone ranged from $2.8 \%$ to $6 \%$ of protein (Capozzi et al., 2020).

The average for moisture were between 41.11 to $42.37 \%$ (Figure 3C), which classifies the mascarpone cheese as medium moisture or semi-hard cheese, between 36 and 46\% (Brasil, 1996). This moisture content indicates an intermediate microbiological risk and defines the need for monitoring total and thermotolerant coliforms, S. aureus, Salmonella sp. and L. monocytogenes in these types of cheese (Brasil, 2001). The average moisture values in Mascarpone cheeses were $53.48 \%$ in a traditional formulation (Almeida et al., 2018), 46\% in a commercial product obtained in Athens, Greece (Kapetanakou et al., 2017) and between 43.83 to $56.02 \%$ in three brands sold in San Luis Obispo, United States (Buratto, 2010), all made from bovine milk.

The average fat content varied between 49.48 and $50.75 \%$ (Figure 3D), with no significant differences between sampling times $(\mathrm{p}<0.05)$. In commercial products, the fat values in Mascarpone were $40 \%$ (Almeida et al., 2018), 42\% (Kapetanakou et al., 2017) 42.5\% (Carvalho et al., 2015) and from 33.3 to $49.8 \%$ (Buratto, 2010), results slightly below those observed in the present study, 

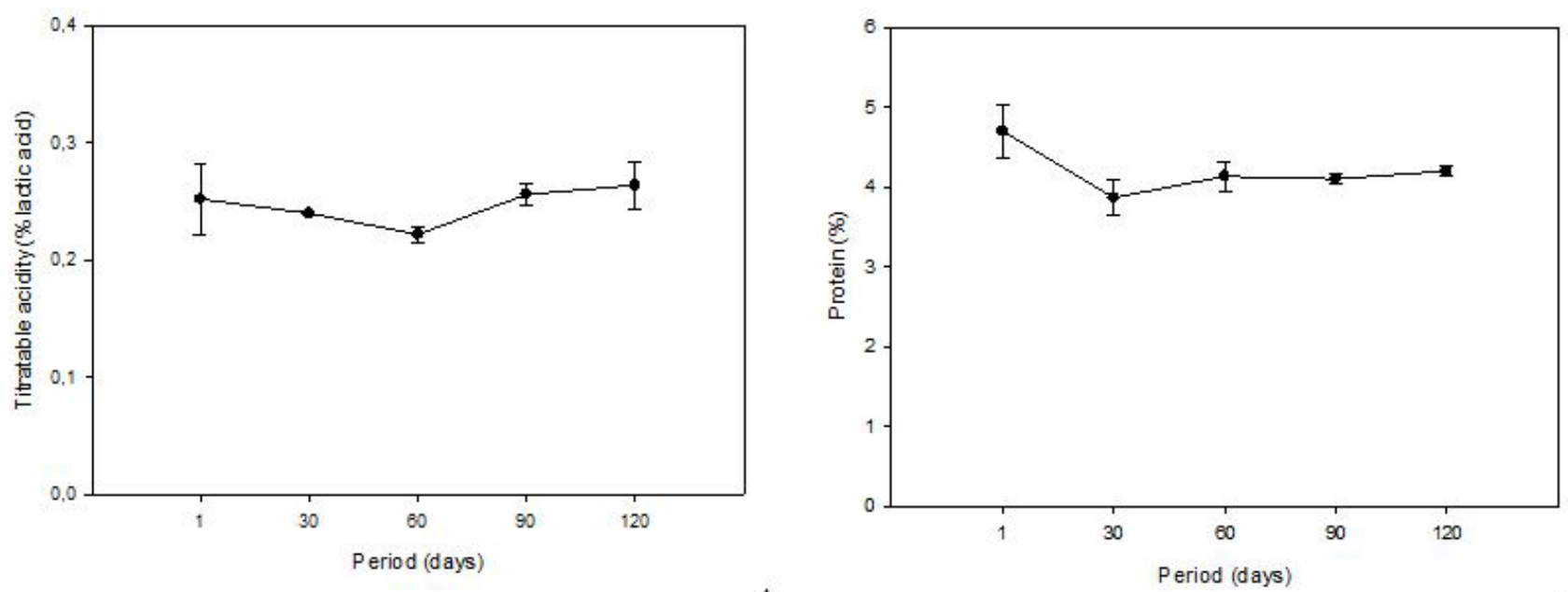

A
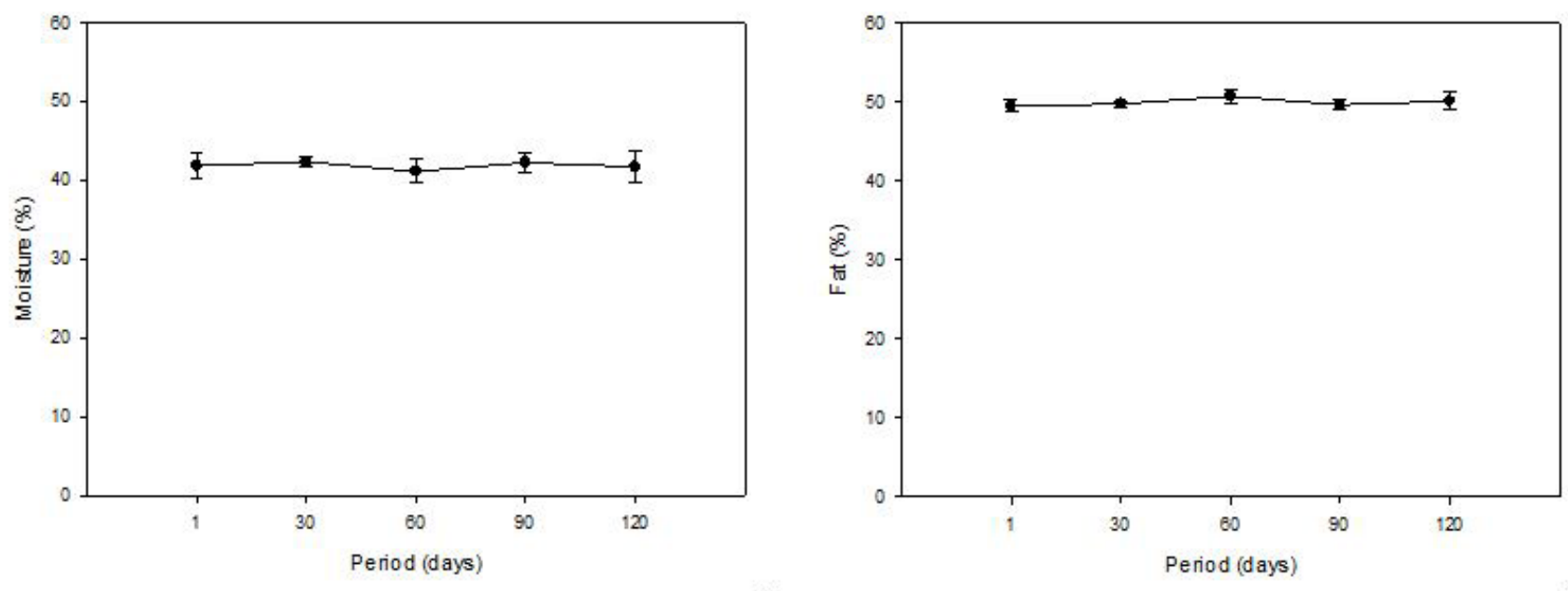

C

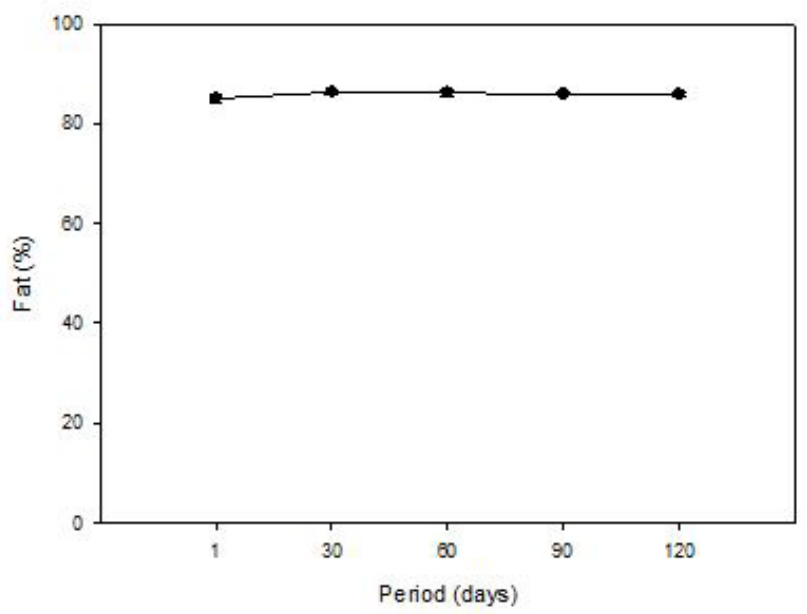

E

Figure 3. Values of titratable acidity (A), Protein (B), Moisture (C), Fat (D) and Fat in dry extract (E) in mascarpone cheese from sheep's milk. The dots indicate the means and the bars indicate the standard deviation of the mean $(n=3)$. 
that can be explained by a higher fat content present in sheep's milk (Munieweg et al., 2017). In six brands of mascarpone marketed in the United States, the values varied between 40 and $50 \%$ of fat (United States Department of Agriculture, 2019). The high fat content in mascarpone attributes sensory characteristics appreciated in the product, such as texture, creamy consistency, flavor and aroma reminiscent of cream or butter (Buratto, 2010; Capozzi et al., 2020; Troiani, 2015). The fat in dry extract values were from 85.05 to $86.35 \%$ without significant variations during storage (Figure $3 \mathrm{E}$ ), which classified it as an extra fat or double cream cheese, as it meets the minimum values of $60 \%$ fat in dry extract (Brasil, 1996). The fat in dry extract in commercial Mascarpone content was $84 \%$ (Kapetanakou et al., 2017), a value similar to ovine Mascarpone.

The evaluation of $\mathrm{pH}$ and water activity $\left(\mathrm{a}_{\mathrm{w}}\right)$ in Mascarpone cheese over refrigerated storage are shown in Table 2. The $\mathrm{pH}$ values showed a with significant reduction over time reaching an acidic $\mathrm{pH}$, which is unfavourable to the development of pathogenic microorganisms (Forsythe, 2013). The $\mathrm{pH}$ values observed in other studies with Mascarpone were 5.50 to 5.74 (Almeida et al., 2018), 5.87 to 6.27 (Tirloni et al., 2017), 6.19 (Carminati et al., 2001) and 6.13 to 6.58 (Buratto, 2010). The higher $\mathrm{pH}$ value does not represent a hurdle to microbial growth (Tirloni et al., 2017), for this reason the values observed after 60 days of cold storage may favor product's shelf life.

The $\mathrm{a}_{\mathrm{w}}$ values (Table 2 ) showed little variation between sampling times, with the collection time of 30 days significantly different $(\mathrm{p}<0.05)$ from the others. The $\mathrm{a}_{\mathrm{w}}$ in mascarpone stored under aerobic conditions at $7^{\circ} \mathrm{C}$ ranged from 0.971 to 0.989 , as observed in mascarpone cheese (0.984) in Italy (Carminati et al., 2001). These $\mathrm{a}_{\mathrm{w}}$ values above 0.85 favor the development of pathogenic bacteria (Forsythe, 2013), which demonstrates the importance of proper processing and refrigeration, so that the product remains in conditions suitable for consumption during its shelf life.

In Brazil, there are only a few initiatives exploring the potential of sheep milk and providing the scientific support for the use of sheep milk in other dairy products beyond yogurt and some types of cheese. These are the reasons why more studies regarding technological and sensory properties of sheep's milk derivatives are so important (Balthazar et al., 2019; Onofre et al., 2020). The use of novel techniques and consumer-based methodologies has been applied to evaluate the sensorial perception about differentiated, unconventional and functional dairy products.

Table 2. Evaluation of $\mathrm{pH}$ and water activity $\left(\mathrm{a}_{\mathrm{w}}\right)$ in sheep's milk mascarpone cheese.

\begin{tabular}{ccc}
\hline Time (Days) & $\mathrm{pH}$ & $\mathrm{a}_{\mathrm{w}}$ \\
\hline 1 & $6.03 \pm 0.06^{\mathrm{a}}$ & $0.995 \pm 0.001^{\mathrm{a}}$ \\
30 & $5.34 \pm 0.22^{\mathrm{b}}$ & $0.979 \pm 0.005^{\mathrm{b}}$ \\
60 & $3.93 \pm 0.07^{\mathrm{c}}$ & $0.993 \pm 0.001^{\mathrm{a}}$ \\
90 & $4.04 \pm 0.07^{\mathrm{c}}$ & $0.995 \pm 0.001^{\mathrm{a}}$ \\
120 & $4.20 \pm 0.21^{\mathrm{c}}$ & $0.989 \pm 0.003^{\mathrm{a}}$ \\
\hline
\end{tabular}

Mean values \pm standard deviation of the mean $(n=3)$; Different letters in the same column indicate a statistically significant difference $(\mathrm{p}<0.05)$.
The free word association method and the completion task can be useful to comprehend the thoughts and feelings about food products and can be explored by the dairy industry in making more competitive products (Judacewski et al., 2019; Torres et al., 2020). The free listing task and preferred attribute elicitation methodologies do not require previous training and allow to assess the perceptions of consumers of dairy products and to develop derivatives with appropriate sensory attributes, in addition to efficient marketing strategies for their commercialization (Soares et al., 2019; Vieira et al., 2020). There is also the quantitative descriptive analysis, which makes it possible to qualify the type and quantify the intensity of sensory properties immediately after the sensory stimulus, and the temporal dominance of sensations, a descriptive technique to provide information about the sequence and duration of the dominant sensations after consuming the food (Silva et al., 2018). All of these methodologies can be employed for describing and optimization of the sensory attributes of different foods, especially novel dairy, and apply efficient marketing strategies for commercialization of these products.

\section{Conclusion}

This study developed a novel formulation of mascarpone cheese produced with sheep milk that showed good results according to microbiological evaluation during the storage time, all within the stipulated by Brazilian legislation, with good composition of nutrients such as protein and fat. The physical-chemical and microbiological parameters remained adequate during the storage period of 120 days, observing a maximum temperature below $7^{\circ} \mathrm{C}$. The Mascarpone cheese produced presented moisture levels that classify it as a medium-moisture or semi-hard cheese and fat in dry extract cheese, which indicate that it is an extra fat or double cream cheese. The production method, packaging and storage conditions proved to be adequate and provided product stability.

\section{Acknowledgements}

We thank the National Council for Scientific and Technological Development (CNPq), Brazil, Research and Innovation Support Foundation of Santa Catarina State (FAPESC), Santa Catarina, Brazil, and Academic Development Program (PDA) of Federal University of Pampa (UNIPAMPA), Rio Grande do Sul, Brazil.

\section{References}

Almeida, J. S. O., Dias, C. O., Pinto, S. S., Pereira, L. C., Verruck, S., Fritzen-Freire, C. B., Amante, E. R., Prudêncio, E. S., \& Amboni, R. D. M. C. (2018). Probiotic Mascarpone type cheese: Characterisation and cell viability during storage and simulated gastrointestinal conditions. International Journal of Dairy Technology, 71, 195-203. http://dx.doi.org/10.1111/1471-0307.12457.

Balthazar, C. F., Pimentel, T. C., Ferrão, L. L., Almada, C. N., Santillo, A., Albenzio, M., Mollakhalili, N., Mortazavian, A. M., Nascimento, J. S., Silva, M. C., Freitas, M. Q., Sant’ana, A. S., Granato, D., \& Cruz, A. G. (2017). Sheep Milk: Physicochemical characteristics and relevance for functional food development. Comprehensive Reviews in Food Science and Food Safety, 16(2), 247-262. http://dx.doi. org/10.1111/1541-4337.12250. 
Balthazar, C. F., Santillo, A., Guimarães, J. T., Capozzi, V., Russo, P., Caroprese, M., Marino, R., Esmerino, E. A., Raices, R. S. L., Silva, M. C., Silva, H. L. A., Freitas, M. Q., Granato, D., Cruz, A. G., \& Albenzio, M. (2019). Novel milk-juice beverage with fermented sheep milk and strawberry (Fragaria $x$ ananassa): Nutritional and functional characterization. Journal of Dairy Science, 102(12), 10724-10736. http://dx.doi.org/10.3168/jds.201916909. PMid:31521367.

Barros, R. F., Torres, F. R., Silva, P. H. F., Stringheta, P. C., Pereira, J. P. F., Paula, J. C. J., Cutrim, C. S., \& Cortez, M. A. S. (2020). Lutein as a functional ingredient in sheep milk yogurt: development, characterization and extraction recovery. Food Science and Technology (Campinas). http://dx.doi.org/10.1590/fst.36019.

Biomérieux (2018). VIDAS Listeria monocytogenes II. Retrieved from: https://nf-validation.afnor.org/wp-content/uploads/2014/03/SyntBIO-12-09-07-02_fr.pdf

Brasil, Ministério da Agricultura, Pecuária e Abastecimento. (1996, March 11). Regulamentos técnicos de identidade e qualidade dos produtos lácteos (Portaria nº 146, de 7 de março de 1996). Diário Oficial [da] República Federativa do Brasil, seção 1.

Brasil, Ministério da Agricultura, Pecuária e Abastecimento. (2018, July 13). Manual de métodos oficiais para análise de alimentos de origem animal (Instrução normativa $n^{\circ} 30$, de 26 de junho de 2018). Diário Oficial [da] República Federativa do Brasil, seção 1.

Brasil, Ministério da Saúde. Agência Nacional de Vigilância Sanitária. (2001, January 10). Aprova o regulamento técnico sobre padrões microbiológicos para alimentos (Resolução RDC $\mathrm{n}^{\circ}$ 12, de 2 de janeiro de 2001). Diário Oficial [da] República Federativa do Brasil.

Buratto, T. (2010). Mastering mascarpone: what it takes to make a perfect batch of mascarpone cheese (Course conclusion monograph). California Polytechnic State University, San Luis Obispo.

Caldera, L., Franzetti, L., Van Coillie, E., Vos, P., Stragier, P., Block, J., \& Heyndrickx, M. (2016). Identification, enzymatic spoilage characterization and proteolytic activity quantification of Pseudomonas spp. isolated from different foods. Food Microbiology, 54, 142-153. http://dx.doi.org/10.1016/j.fm.2015.10.004.

Capozzi, V., Lonzarich, V., Khomenko, I., Cappellin, L., Navarini, L., \& Biasioli, F. (2020). Unveiling the molecular basis of mascarpone cheese aroma: VOCs analysis by SPME-GC/MS and PTR-ToF-MS. Molecules (Basel, Switzerland), 25(5), 1-14. http://dx.doi.org/10.3390/ molecules25051242. PMid:32164157.

Carminati, D., Perrone, A., \& Neviani, E. (2001). Inhibition of Clostridium sporogenes growth in mascarpone cheese by co-inoculation with Streptococcus thermophilus under conditions of temperature abuse. Food Microbiology, 18(6), 571-579. http://dx.doi.org/10.1006/ fmic.2001.0426.

Carvalho, T., Sousa, S. C., Perez-Matín, R. I., Vasquez, J. A., Carvalho, A. P., \& Gomes, A. M. (2015). Physical and chemical characterization of mascarpone cheese with fish gelatin as a fat substitute. In $3 r d$ International Conference WASTES: Solutions, Treatments, Opportunities, Viana do Castelo, Portugal.

European Comission - EC. (2017). Guidance document describing the food categories in Part E of Annex II to Regulation (EC) No 1333/2008 on Food Additives. Official Journal of the European Union. Retrieved from: https://ec.europa.eu/food/sites/food/files/safety/docs/fs_foodimprovement-agents_guidance_1333-2008_annex2.pdf

Facchin, S., Barbosa, A. C., Carmo, L. S., Silva, M. C. C., Oliveira, A. L., Morais, P. B., \& Rosa, C. A. (2013). Yeasts and hygienicsanitary microbial indicators in water buffalo mozzarella produced and commercialized in Minas Gerais, Brazil. Brazilian Journal of
Microbiology, 44(3), 701-707. http://dx.doi.org/10.1590/S151783822013000300006. PMid:24516436.

Forsythe, S. J. (2013). Microbiologia da Segurança dos Alimentos (2. ed.). Porto Alegre: Artmed.

Funck, G. D., Hermanns, G., Vicenzi, R., Schmidt, J. T., Richards, N. S. P. S., Silva, W. P., \& Fiorentini, A. M. (2015). Microbiological and physicochemical characterization of the raw milk and the colonial type cheese from the Northwestern Frontier region of Rio Grande do Sul, Brazil. Revista do Instituto Adolfo Lutz, 74(3), 247-257.

Judacewski, P., Los, P. R., Lima, L. S., Alberti, A., Zielinski, A. A. F., \& Nogueira, A. (2019). Perceptions of Brazilian consumers regarding white mould surface-ripened cheese using free word association. International Journal of Dairy Technology, 72(4), 585590. http://dx.doi.org/10.1111/1471-0307.12649.

Kapetanakou, A. E., Gkerekou, M. A., Vitzilaiou, E. S., \& Skandamis, P. N. (2017). Assessing the capacity of growth, survival, and acid adaptive response of Listeria monocytogenes during storage of various cheeses and subsequent simulated gastric digestion. International Journal of Food Microbiology, 246, 50-63. http://dx.doi.org/10.1016/j. ijfoodmicro.2017.01.015. PMid:28189900.

Lim, C. W., Lai, K. Y., Ho, W. T., \& Chan, S. H. (2019). Isotopic dilution assay development of nisin A in cream cheese, mascarpone, processed cheese and ripened cheese by LC-MS/MS method. Food Chemistry, 292, 58-65. http://dx.doi.org/10.1016/j.foodchem.2019.04.040. PMid:31054692.

METER Group. (2018). Aqualab 4. Retrieved from: http://library. metergroup.com/Manuals/20779_METER\%20AquaLab4_ Manual_Web.pdf

Munieweg, F. R., Nespolo, C. R., Pinheiro, F. C., Gavião, E. R., Pinheiro, F. C., \& Czarnobay, M. (2017). Qualidade do leite cru ovino armazenado sob refrigeração. Vigilância Sanitária em Debate: Sociedade. Ciência \& Tecnologia, 5(1), 52-59. http://dx.doi. org/10.3395/2317-269x.00848.

Nespolo, C. R., \& Brandelli, A. (2012). Characterization of cheeses produced with ovine and caprine milk and microbiological evaluation of processing areas in the dairy plant in Brazil. International Food Research Journal, 19(4), 1713-1721.

Onofre, E. O., Nespolo, C. R., Sehn, C. P., Pinheiro, F. C., \& Stefani, L. M. (2020). Lactic acid bacteria with antimicrobial, proteolytic and lipolytic activities isolated from ovine dairy products. Food Science and Technology, 40(Suppl. 1), 293-299. http://dx.doi.org/10.1590/ fst.11019.

Silva, N., Junqueira, V. C. A., Silveira, N. F. A., Taniwaki, M. H., Gomes, R. A. R., \& Okazaki, M. M. (2017). Manual de métodos de análise microbiológica de alimentos e água (5. ed.). São Paulo: Varela.

Silva, H. L. A., Balthazar, C. F., Silva, R., Vieira, A. H., Costa, R. G. B., Esmerino, E. A., Freitas, M. Q., \& Cruz, A. G. (2018). Sodium reduction and flavor enhancer addition in probiotic prato cheese: Contributions of quantitative descriptive analysis and temporal dominance of sensations for sensory profiling. Journal of Dairy Science, 101(10), 8837-8846. http://dx.doi.org/10.3168/jds.201814819. PMid:30077456.

Soares, E. K. B., Silva, R., Silva, W. P., Kuriya, S. P., Maçaira, P. M., Oliveira, F. L. C., Silva, M. A. A. P., Pimentel, T. C., Freitas, M. Q., Cruz, A. G., \& Esmerino, E. A. (2019). An intra-cultural investigation in Brazil using Coalho cheese and preferred attribute elicitation. Journal of Sensory Studies, 53(1), e12543. http://dx.doi. org/10.1111/joss.12543.

Tirloni, E., Ghelardi, E., Celandroni, F., Bernardi, C., \& Stella, S. (2017). Effect of dairy product environment on the growth of Bacillus 
cereus. Journal of Dairy Science, 100(9), 7026-7034. http://dx.doi. org/10.3168/jds.2017-12978. PMid:28711259.

Torres, F. A., Silva, H. L. A., Cutrim, C. S., \& Cortez, M. A. S. (2020). Consumer perception of Petit-Suisse cheese: identifying market opportunities for the Brazilian dairy industry. Food Science and Technology. http://dx.doi.org/10.1590/fst.38319.

Tribst, A. A. L., Falcade, L. P., Leite Júnior, B. R. C., \& Oliveira, M. M. (2020). Why are most physicochemical parameters not useful in predicting the quality of sheep milk? International Journal of Dairy Technology, 73(1), 292-295. http://dx.doi.org/10.1111/1471-0307.12657.

Troiani, C. (2015, July 12). La solida nicchia del mascarpone. Il Latte. Retrieved from https://www.lattenews.it/la-solida-nicchia-del-mascarpone/
United States Department of Agriculture - USDA. (2019). FoodData Central - Mascarpone. USDA. Retrieved from https://fdc.nal. usda.gov/

Vieira, A. H., Balthazar, C. F., Rocha, R. S., Silva, R., Guimaraes, J. T., Pagani, M. M., Pimentel, T. C., Esmerino, E. A., Silva, M. C., Tonon, R. V., Cabral, L. M., Freitas, M. Q., \& Cruz, A. G. (2020). The free listing task for describing the sensory profiling of dairy foods: A case study with microfiltered goat whey orange juice beverage. Journal of Sensory Studies, 12594. http://dx.doi. org/10.1111/joss.12594.

Zucatti, K. P., Czarnobay, M., \& Nespolo, C. R. (2015). Ovinocultura leiteira na Serra Gaúcha: composição do leite de diferentes propriedades perspectivas para o setor. In $5^{\circ}$ Simpósio de Segurança Alimentar, Bento Gonçalves, Brazil: sbCTA. 